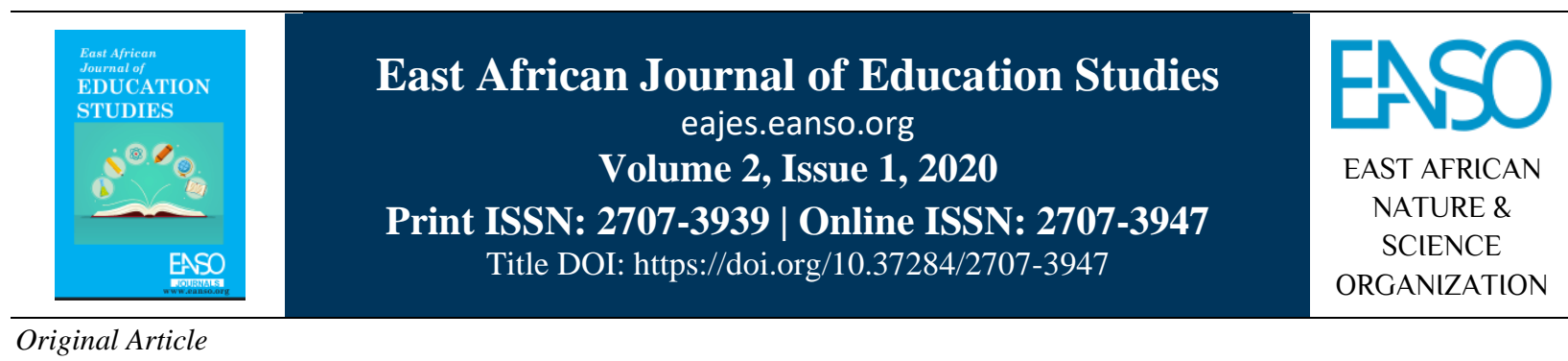

\title{
Influence of the Balanced Diet on Enrolment in ECE Centres in Turkana Central Sub County, Turkana County, Kenya
}

\author{
Locha Erukudi ${ }^{1 *} \&$ Dr. Paul Edabu, PhD ${ }^{1}$ \\ ${ }^{1}$ School of Education, Mount Kenya University, P. O. Box 342-01000 Thika, Kenya. \\ *Author for Correspondence Email: lochaerukudi@gmail.com.
}

Article DOI: https://doi.org/10.37284/eajes.2.1.238

\section{Date Published: ABSTRACT}

23 November 2020 School Feeding Programmes (SFP) were created for the purpose of eradicating hunger, supporting education, health and development. Although SFP is Keywords: offered in Kenya, approximately 55\% of children in do not go to school.

Balanced Diet, Enrolment, Feeding Programme, School Enrolment, Turkana County. According to CBS, roughly $50 \%$ of ECDE children do not attend school in Turkana Central Constituency. Therefore, the introduction of SFP in schools was envisioned to improve enrolment in schools. This study sought to establish the influence of SFP on children enrolment in early childhood education centres in Turkana Central Sub-County, Kenya. The specific objective was to determine the influence of the balanced diet on student enrolment in ECE centres in Turkana Central Sub County, Kenya. The study was based on program. The study used a mixed research method. The study adopted a crosssectional research design. The target population was 250 schools, 78 teachers and headteachers and 5,000 parents in pre-schools in Turkana Central Sub County. The study used purposive sampling to select respondents. The sample size of the study was 150 schools, 60 teachers and headteachers and 357 parents. Primary data was gathered by the use of questionnaires and interview guides. Secondary data consisted of report forms of pre-schoolers. Quantitative information was analysed using descriptive statistics. Qualitative data was analysed using content analysis. Multiple regression was done to analyse the influence of SFPs on children enrolment in ECDE centres the county. The study found that a balanced diet positively relates to children enrolment in ECE centres in Turkana Central Sub County. The study therefore recommends the government to increase food supply to ensure adequacy. There is a need to continue the supply of balanced diet to children because it improves their growth and learning. Some of the children are from very poor families and 
during school holidays they suffer because of lack of food; the study, therefore, recommends orphans, poor and disabled to be fed even during holidays.

\begin{abstract}
APA CITATION
Erukudi, L., \& Edabu, P. (2020). Influence of the Balanced Diet on Enrolment in ECE Centres in Turkana Central Sub County, Turkana County, Kenya. East African Journal of Education Studies, 2(1), 150-160. https://doi.org/10.37284/eajes.2.1.238.
\end{abstract}

\title{
CHICAGO CITATION
}

Erukudi, Locha, and Paul Edabu. 2020. "Influence of Instructional Resources Provision and Performance in Mathematics Subject in Public Girls Secondary Schools Baringo Central Sub-County". East African Journal of Education Studies 2 (1), 150160. https://doi.org/10.37284/eajes.2.1.238.

\section{HARVARD CITATION}

Erukudi, L. and Edabu, P. (2020) "Influence of the Balanced Diet on Enrolment in ECE Centres in Turkana Central Sub County, Turkana County, Kenya”, East African Journal of Education Studies, 2(1), pp. 150-160. doi: 10.37284/eajes.2.1.238.

\section{IEEE CITATION}

L. Erukudi, and P. Edabu, "Influence of the Balanced Diet on Enrolment in ECE Centres in Turkana Central Sub County, Turkana County, Kenya”, EAJES, vol. 2, no. 1, pp. 150-160, Nov. 2020.

\section{MLA CITATION}

Erukudi, Locha, and Paul Edabu. "Influence of the Balanced Diet on Enrolment in ECE Centres in Turkana Central Sub County, Turkana County, Kenya”. East African Journal of Education Studies, Vol. 2, no. 1, Nov. 2020, pp. 150-160, doi:10.37284/eajes.2.1.238.

\section{INTRODUCTION}

Food and Agricultural Organization (FAO, 2012) statistics showed that 923 million people globally suffer from hungry; this is a rise of 75 million persons from estimates done from 2009 to 2010. A great number of individuals were children and people in developing nations. This is an implication that Millennium Development Goals (MDGs) linked to alleviation of hunger as well as malnutrition was not achieved in 2015. School feeding programmes (SFP) were introduced in many developing nations as a way to mitigate hunger and it is also one of the MDGs. School feeding programme (SFP) is a form of intervention aimed at improving the enrolment and attendance of school-aged children in schools (FAO, 2012).

Task Force Report of the MDGs indicated that after attainment of educational millennium goals they would focus on school feeding programmes as an essential method to draw children to schools. SFPs are important in the provision of balanced meals to early childhood school children; this assist to improve children's attention in the classroom hence improve their performance. School feeding programmes are also essential for children's growth. It helps in preventing malnutrition of the children aged between zero to eight years which can be distressing (Birdsall, Levin \& Ibrahin, 2005).

In Pakistan, a programme financed by the World Food Programme (WFP) provided packaged food as a reward for the families that allow their girls to attend school for more than 21 days each month. While the school's enrolment rose by $76 \%$ in comparison to $14 \%$ in the area. Attendance also increased from $76 \%$ to $93 \%$ (WFP, 2015). In Bhutan, SFPs provided an additional meal for learner's, therefore, increasing attendance in lower grades schools. School enrolment gained an upward trend since the demand for schools already outstrips supply (WFP, 2014). Simeon and Granham (2009) carried out research in India on SFP and children's performance and found that providing improved school nutrition may lead to better performance, reduced repetition grades and dropouts.

Inadequate financing as well as lack of support from stakeholders affects the smooth running of the school feeding programme (Ndung'u, 2010). Food scarcity in semi-arid and arid regions might limit the number of servings per day and hinder the availability of various foods which are important for balanced meals. More so, factors related to needs assessment, regulatory frameworks, community participation, financial management 
and policy also deter the running of school feeding programmes. A study carried out in Emuhaya SubCounty, Kenya revealed that the provision of SFP is deterred by failure to reflect on all challenges, opportunities and any arising issues as well as stakeholder's involvement (Olubayo, Amisialuvi \& Namusonge, 2013). It was concluded that lack of capacity to plan, manage budget needs, lack of implementing units and arrangements, lack of staff training on knowledge of SFP, lack of monitoring and evaluation and failure to consult the community when designing an SFP led to the collapse of the programme

According to the Central Bureau of Statistics (CBS, 2011) in Kenya, many preschool pupils are highly or a little bit malnourished. CBS also found that a third of Kenyans children below 5 years have severe or mild malnutrition. Undernutrition is seen as a risk which has an effect on children's education in the future and therefore the government and other non-governmental organizations should work together to help improve the nutrition of children (Pollit, 1990). The school feeding initiative in Kenya started with WFP collaborating with the government in 1980. Free Primary Education (FPE) was introduced to all government primary schools by the Kenyan government in 2003, with the objective of improving children's enrolment and attendance in schools. Despite the two initiatives, school enrolment and attendance are still low (less than 50\%) (CBS, 2011). This study sought to establish the impact of SFP on children enrolment in ECDE centres in Turkana Central Sub County in Kenya.

\section{Statement of the Problem}

School Feeding Programme was created for the purpose of eradicating hunger, supporting education, health and development (WFP, 2007). The programme provides meals and snacks which are consumed at school while some are taken home. Proponents of SFP claim that provision of meals in schools would attract children to schools. Further, according to the WFP, food acts as motivation to the needy families to invest in educating their kids and send them to school (WFP, 2008).

In times of crisis such as war and drought, East Africa has used school feeding as a key strategy in combating scarcity of food. In times that crises are acute, for instance when schools are not running, the SFPs become less priority and serves as supplements to food aid given to households (Bennett, 2003). When a country is faced with crises it is common to see children withdrawn from school to help their families in generating income, and in such a case, SFP can assist as they can act as encouragements to motivate children to get enrolled back to school. Additionally, when schools are in operation, they can operate as both direct (meals to take home) and indirect (meals at school).

Although SFP is offered in Kenya, approximately $55 \%$ of children in Kenya do not go to school. According to the Central Bureau of Statistics (2016), roughly 50\% of ECDE children do not attend school in Turkana Central Constituency. Lack of tuition, lack of uniform, sickness, family affairs, movement of families from one place to another as well as lack of food are major contributors to low attendance and enrolment in schools (Allen, 2011). Therefore, the introduction of SFP in schools might improve enrolment in schools. Burbano, Neeser and Bundy (2009) argued that feeding programs can be introduced in schools to increase the rate of attendance and enrolment especially if the program is incorporated in comprehensive school health and nutrition programs. Similarly, Jomaa, McDonnell and Probart (2011) revealed a positive relationship between SFP and school enrolment and attendance.

Though SFPs are available in some pre-schools in Kenya, school enrolment and attendance are still low as a result of minimal government support of the programme. Inadequate and underfunding in some regions in Kenya also affect the sustainability of SFPs. Turkana Central Sub County is not singled out since it has low pre-school enrolment and attendance. Turkana Central Sub County is also faced with hunger due to the drought experienced in the region for long a period, this affects children's enrolment in ECDE. The purpose of the study was to investigate the influence of SFPs on children enrolment in ECE centres in Turkana Central Sub County, Turkana County, Kenya. The study objective was to

determine the influence of the balanced diet on enrolment in ECE centres in Turkana Central Sub 
County, Turkana County, Kenya. It was hypothesised that:

$H_{0}$ : Balanced diet has a positive influence on enrolment in early childhood education centres in Turkana Central Sub County, Turkana County, Kenya.

\section{THEORETICAL REVIEW}

\section{The Program Theory}

The study was guided by the program theory whose proponent was (Vroom, 1964). Based on this theory, the likelihood of performing in a given manner depends on the intensity of the performance that is expected which is followed by an outcome that is defined and on the appearance of the results to a person. Tolman (1932) did attribute the outcome of reinforcement to learning and not as if it is a necessity to ensure that learning continues. For children especially the ones in semi-arid regions who face hunger and starvation because of the conditions they live in will be encouraged to continue with their education with the hope that they will receive food. According to Vroom's theory, valence refers to being emotionally oriented toward a certain result or whether the value of a person is attached to the result. The result is its attractiveness or performance for a certain result.

The theory assumes that individuals join an institution with clear expectations of their needs, motivation and environment, individual behaviour is typically their conscious decision. Individuals seek to fulfil different goals and needs hence prone to choose among the alternatives in order to optimize their outcome. The theory has been criticized in that it states only the conceptual determinant and their relationships and does not provide suggestions on the things motivating people like other models like Maslow, Herzberg and Alderfer do. The theory is complex and its validity cannot be fully tested.

The SFP acts as a motivator in attracting school attendance among children and allow them to learn. Expectancy refers to the momentary belief that is concerned with the likelihood that a certain act will attract particular results (being convinced that certain acts will lead to improved performance). Thus, the mentality that good performance results in valid outcomes. For the child expectancy, it is the inward belief that attending school on a regular basis will allow them to acquire quality education that will empower them to be free from hunger pain and in the future from floods.

\section{The Influence of the Balanced Diet on Enrolment in Early Childhood Education Centres}

Children who receive a balanced diet grow faster. Those children are very active, and they regularly attend school, they are highly motivated and they are healthy looking. They are very attentive in class and all their senses function well (Omoro, 2011). In order to have proper growth, nutrition is very important, it also helps in the development, health and well-being of an individual this is because the survival of humans depends on food (Ake-Tano et al., 2011). Nutrition that is good assists in improving the survival of children, promoting healthy growth and contribute improved development in their cognition and also in the economy. Other advantages are that the rate of mortality decreases, risk of other chronic illnesses like cardiovascular, diabetes, kwashiorkor, marasmus, hypertension, not only in children but also in adults (OMS, 2010). The state of nutrition of an individual is the measure of the degree of his/her nutritional and physiological requirements are met. It's also the health status of an individual which is a result of a balance in intake of nutrients and how the body utilizes them (Halterman, 2001).

In India, it is approximated that about 100 million pupils in 265,000 schools get access to balanced meals for their midday meals. The Supreme Court in India gave an order in 2001 that the government had to provide meals in all the primary schools of at least 300 calories and that of proteins $8-12 \mathrm{~g}$, and the majority of them are using produces that are produced locally (Government of India, 2014). From the year 2005, the government of Ghana also started to support the SFP by procuring food from farmers locally. Currently, 4,000 schools are involved in the initiative where they serve more than 1.6 million children. Their former President John Kufuor stated that the relationship of farmschool is a win-win one because it has a great positive effect on the economy of the country (Peel, 2013). 
In the UK, Great Britain and Northern Ireland, the diet that is provided during the infant stage relates with the intelligence of the child in the midchildhood and adolescence stages of their lives (Gale et al., 2009). Also, in New Zealand, it was established that cognitive skills and diet were positively related; it was found so at the ages of 3.5 and 7 years. In Australia, it was further established that children who had healthy diets in their infancy had high verbal as well as non-verbal abilities in their mid-childhood (Nyaradi et al., 2013). Since a specific diet affects some specific results that are very crucial in attaining the education of a child, other authors did a test of the relationship between diet and grades attained or the standard scores attained.

Physical, intellectual and emotional development requires good nutrition. In Asia, there is a high number $(70 \%)$ of children who suffer from proteinenergy malnutrition. Despite the fact that food is important most of the time it lacks in quality and quantity and the result is malnutrition. Developing nations face the issue of malnutrition as a problem to the health of the public (Asres and Eidelman, 2011). The pre-school children are young and therefore they are more vulnerable compared to the older children. A study conducted by Bellisle (2004) on impacts of breakfast on cognition established that missing breakfast especially for the younger children greatly affects their general levels of energy and cognition. Bellisle (2004) also indicated that taking breakfast led to improved scores on three distinct tests.

The findings of studies that were conducted in Kenya regarding nutrition showed that the state of nutrition among children aged less than 5 is deteriorating. Western and Nyanza regions showed the highest rate of deterioration (WHO, 2019). It has a significant effect on preschool children which seriously affects their health and also learning activity. $37 \%$ of children in Western Province were stunted which is more than the national rate of $33.6 \%$. The greatest percentage $(12.5 \%)$ of wasted children was reported in Vihiga District in comparison to other regions in the area (Central Bureau of Statistics, 2016). Other districts showed high levels of underweight and stunting.

\section{RESEARCH METHODOLOGY}

\section{Location of the Study}

The study location was Turkana County, Kenya, specifically the sub-county of Turkana Central. Turkana Central Sub County covers an area of 4906.50 square kilometres with a population of approximately 134,647 people (2009 Census report). The main economic activities in the area are livestock keeping, fishing, and burning of charcoal and crop farming for those along the Lake Turkana regions. A good number of people are employed in various government and private sector institutions for example the Ministry of Health, the mental health and the defence ministry. However, $86.4 \%$ of the population is still illiterate due to the culture and nature of climate which is very dry thus encouraging people to practice nomadic Pastoralism (Turkana County Government strategic plan, 2015).

\section{Research Methodology}

The study used a mixed research method where quantitative and qualitative data was collected. A cross-sectional research was adopted as the researchers investigated the state of affairs in a population at a certain point in time

The target population for this study was 250 schools, 78 teachers and headteachers and 5,000 parents in pre-schools in Turkana Central Sub County. At least $30 \%$ and above of the study population is enough for research on social science (Orodho, 2013). The study used purposive sampling to select the respondents. The representative sample was selected through the researcher's expert judgment. Picking cases that were involved in the study using an individual's judgment is known as purposive sampling.

Both secondary and primary data were used. Primary data was gathered by the use of questionnaires and interview guides. Secondary data consisted of report forms of pre-schoolers. Both open and closed-ended questions were used and they were distributed to headteachers and ECD teachers. Interview Schedules are designed in a standard form. This implies that similar questions are asked to every interviewee in a similar order. 


\section{Data Analysis}

Quantitative information was analysed using descriptive statistics which was computed using SPSS version 21. Presentation of the findings was done using frequencies, percentages, means and standard deviation and displayed on pie-charts, bar charts and graphs. Qualitative data was analysed using content analysis. If the value of correlation is 0 suggests there is no relationship between the variables. A value of \pm 1.0 implies that there exists a perfect relationship that could either be positive or negative (Hair et al., 2013). Interpretation of the values was as follows; ' 0 - no relationship', and ' 1.0 perfect relationship'. When ' $r= \pm 0.1$ to \pm 0.29 ' the relationship is small, when ' $\mathrm{r}= \pm 0.3$ to \pm 0.49 ' the relationship medium and the relationship is strong when $r_{=} \pm 0.5$. Multiple regressions were done to analyse the influence of the balanced diet on enrolment in ECE centres in Turkana Central Sub County, Turkana County, Kenya. Multiple regressions measured quantitative data. The equation was modelled as:

$$
Y=\beta_{0}+\beta_{2} X_{2}+\varepsilon
$$

Where: $\quad \mathrm{Y}=$ enrolment in early childhood education; $\beta_{0}=$ Constant term; $\mathrm{X}_{2}=$ Balanced Diet; $\varepsilon=$ error term; $\beta_{2}$, coefficients of determination

\section{RESEARCH FINDINGS AND DISCUSSION}

\section{Influence of Balanced Diet on Enrolment in ECE Centres}

\section{a) Teachers}

The statements were interpreted using mean values where a mean value of 1-1.4 was strongly disagreed, 1.5-2.4 disagree, 2.5-3.4 neutral, 3.5-4.4 agree and 4.5-5 strongly agree. The results were as presented in Table 1.

Table 1: Teachers Views on the Influence of Balanced Diet on Enrolment in ECE Centers

\begin{tabular}{|c|c|c|c|c|c|}
\hline & $\mathbf{N}$ & Min. & Max. & Mean & $\begin{array}{l}\text { Std. } \\
\text { Dev }\end{array}$ \\
\hline $\begin{array}{l}\text { The government help in improving meals in schools through } \\
\text { the use of foods provided locally }\end{array}$ & 53 & 1 & 5 & 2.5 & 1.56 \\
\hline $\begin{array}{l}\text { Good nutrition is essential for physical, intellectual and } \\
\text { emotional development }\end{array}$ & 53 & 1 & 5 & 4.29 & 1.33 \\
\hline $\begin{array}{l}\text { The meals provided are of the required protein standard and } \\
\text { micronutrients (e.g., iron, calcium, vitamin } \mathrm{A} \text { and } \mathrm{C} \text { ) }\end{array}$ & 53 & 1 & 5 & 3.53 & 1.55 \\
\hline $\begin{array}{l}\text { The students are provided with fruits twice a week which are } \\
\text { essential for the normal growth }\end{array}$ & 53 & 1 & 2 & 1.07 & 0.27 \\
\hline Pupils are served natural food such as rice, maize and beans & 53 & 3 & 5 & 4.71 & 0.61 \\
\hline School meals have mandatory nutrient-based guidelines. & 53 & 1 & 5 & 3.36 & 1.55 \\
\hline
\end{tabular}

From the findings, teachers strongly agreed that pupils are served natural food such as rice, maize and beans $(M=4.71)$; they also agreed that good nutrition is essential for physical, intellectual and emotional development $(M=4.29)$ and that the meals provided are of the required protein standard and micronutrients (e.g., iron, calcium, vitamin A and C) $(M=3.53)$. In addition, that had neutral feelings on the idea that school meals have mandatory nutrient-based guidelines $(M=3.34)$ and that the government help in improving meals in schools through the use of foods provided locally $(M=2.5000)$. Teachers also disagreed that the students are provided with fruits twice a week which are essential for normal growth $(M=$ 1.0714). These findings suggest that schools in Turkana Central Sub County are provided with food of required protein standard and micronutrients (e.g., iron, calcium, vitamin A and C) and these allow them to serve their pupils with natural healthy foods such as rice, maize and beans. This is important because food nutrition is essential for physical, intellectual and emotional development. In addition, not all school meals have mandatory nutrient-based guidelines. Furthermore, despite the fact that schools are provided with food, the government doesn't fully use foods provided locally. Meals served for pupils in Turkana Central 
Sub County do not include fruits which are essential for normal growth.

According to Ake-Tano et al. (2011) children who receive a balanced diet grow faster; those children are very active, and they regularly attend school, they are highly motivated and they are healthy looking; they are very attentive in class and all their senses function well. In order to have proper growth, nutrition is very important, it also helps in the development, health and well-being of an individual this is because the survival of humans depends on the food. Also, nutrition that is good assists in improving the survival of children, promoting healthy growth and contribute to improved development in their cognition and also in the economy.

\section{b) Parents}

Parents were asked to indicate whether the school provided a balanced diet and provide an explanation for their opinion. From the findings, $86 \%$ of the parents agreed that school provide a balanced diet while only $14 \%$ disagreed. Those parents who indicated that schools provide their children with a balanced diet explained that the school provided beans for proteins, rice and maize for carbohydrates and oil which formed a balanced meal. Parents also indicated that since the introduction of School Feeding Programs they have observed some improvement in their children. Their health has improved and their growth is good. They also indicated that their children have become more involved, active, are more energetic and learn well.

Parents were further requested to indicate whether their children's reaction was about the food provided in school. Parents indicated that children react positively towards the food they are provided with at school. Since the food provided is good, the children are happy and learn well. Because most of the children are not able to get food at home, they are excited to attend school because they are sure they will get food. They added that their children have benefited from the school feeding program because they get their daily basic meals which has improved their health and encouraged them to attend school frequently. Another benefit is that children are motivated to work hard in their studies.

Parents were requested to indicate whether they go to school to discuss the nutritional value of the school feeding programme. The results were as presented in Figure 1.

Figure 1: Parents School Attendance to Discuss SFP

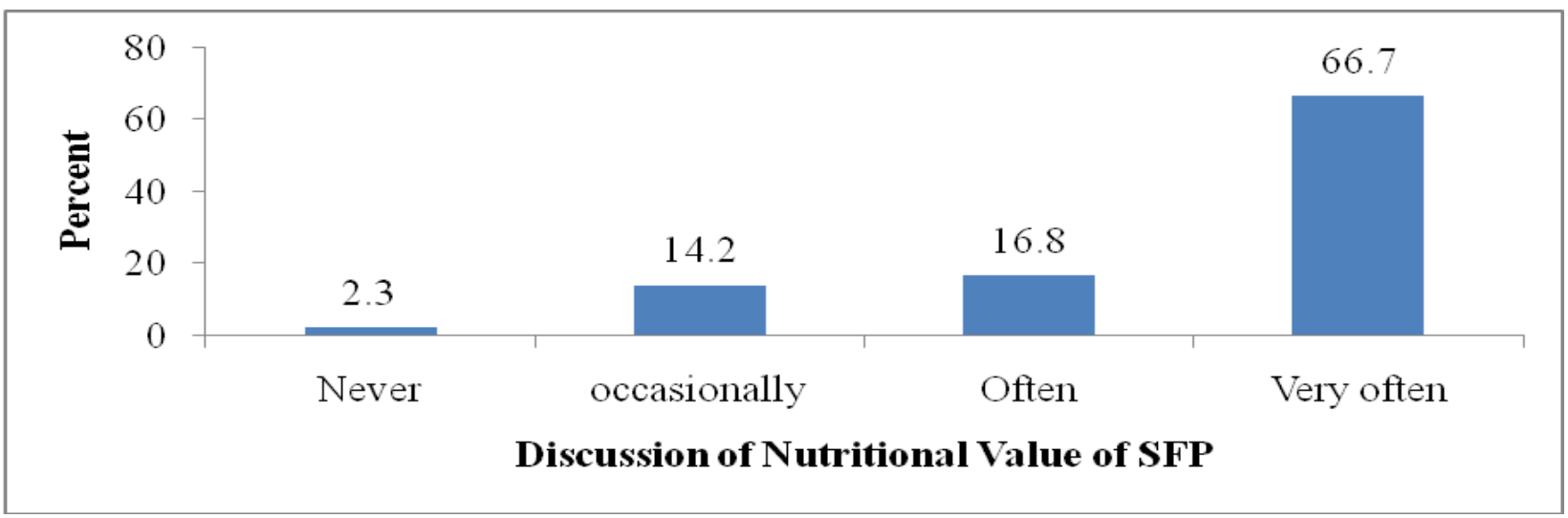

From the findings, the majority $(66.7 \%)$ of parents indicated that they go to school very often to discuss the nutritional value of the school feeding programme, $16.8 \%$ indicated they go often, $14.2 \%$ indicated occasionally while $2.3 \%$ indicated never. This, therefore, suggests that the majority of the parents with pre-school going children go to school to discuss the nutritional value of the school feeding programme.

\section{Correlation Analysis}

Karl Pearson's product-moment correlation coefficient was used in conducting correlation 
analysis. Correlation Coefficient was applied in testing if there is a case of interdependence among the variables and whether predictor variables are associated with the response variable. The findings were as presented in Table 2.

Table 2: Correlation Analysis between Balanced Diet and School Enrolment in ECD

\begin{tabular}{llll}
\hline & & School Enrolment in ECD & Balanced Diet \\
\hline School Enrolment in ECD & Pearson Correlation & 1 & \\
& Sig. (2-Tailed) & & \\
& $\mathrm{N}$ & 53 & 1 \\
Balanced Diet & Pearson Correlation & $.716^{* *}$ & \\
& Sig. (2-Tailed) & .004 & 53 \\
\hline
\end{tabular}

From the findings, there is a strong positive association between a balanced diet and school enrolment with ECD $(r=0.716, p=0.004)$. This finding therefore suggests that food adequacy,

\section{Multiple Regression Analysis}

Table 3: Multiple Regression Analysis Model Summary

\begin{tabular}{lllll}
\hline Model & $\mathrm{R}$ & R Square & Adjusted R Square & Std. Error of the Estimate \\
\hline 1 & $.775^{\mathrm{a}}$ & .601 & .423 & .55878 \\
\hline a. & Predictors: (Constant), Food preparation, Balanced diet, Consistency of food delivery, Food adequacy \\
\hline
\end{tabular}

From the findings, the value of adjusted $\mathrm{R}^{2}$ was 0.423 , suggesting that $42.3 \%$ variation in school enrolment in ECD can be explained by changes in food adequacy, balanced diet, consistency of food delivery and food preparation was analysed. The remaining $57.7 \%$ suggests that there are other balanced diet, consistency of food delivery and food preparation influence school enrolment in ECD.

\section{Analysis of Variance}

Table 4: Analysis of Variance

\begin{tabular}{llllll}
\hline Model & Sum of Squares & df & Mean Square & F & Sig. \\
\hline Regression & 161.907 & 4 & 40.477 & 9.387 & $.009^{\mathrm{b}}$ \\
1 Residual & 206.976 & 48 & 4.312 & & \\
Total & 368.883 & 52 & & & \\
a. Dependent Variable: School Enrolment in ECD & & & \\
b. Predictors: (Constant), Food preparation, Balanced diet, Consistency of food delivery, Food adequacy \\
\hline
\end{tabular}

The $\mathrm{p}$-value obtained was 0.009 which is less than $0.05 \quad(0.009<0.05)$ therefore the model was considered significant. In addition, the value of Fcalculated was 9.387 while the F-critical value obtained from the f-distribution tables was 2.565. Since the $\mathrm{f}$ critical value was less than the f- factors that can be attributed to changes in school enrolment in ECD that were not included in this model. The findings also suggest that the variables included in this model are strongly and positively related as indicated by the correlation coefficient value $(\mathrm{R})$ of 0.775 . calculated value $(9.387>2.565)$ it suggests that there is a significant linear relationship existing between food preparation, balanced diet, consistency of food delivery, and food adequacy with school enrolment in ECD. 
East African Journal of Education Studies, Volume 2, Issue 1, 2020

Article DOI: https://doi.org/10.37284/eajes.2.1.238

Beta Coefficients of the Study Variables

\begin{tabular}{|c|c|c|c|c|}
\hline \multirow[t]{2}{*}{ Model } & \multicolumn{2}{|c|}{ Unstandardized Coefficients } & \multirow{2}{*}{$\begin{array}{l}\text { Standardized Coefficients } \\
\text { Beta }\end{array}$} & \multirow[t]{2}{*}{ t $\quad$ Sig. } \\
\hline & B & Std. Error & & \\
\hline (Constant) & 0.765 & 0.101 & & 7.5740 .001 \\
\hline${ }^{1}$ Balanced diet & $\begin{array}{l}0.228 \\
\text { iable. }\end{array}$ & $\begin{array}{l}0.039 \\
\text { Enrolment in FC }\end{array}$ & 0.198 & 5.8460 .029 \\
\hline
\end{tabular}

The modelled regression equation was;

$\mathrm{Y}=0.765+0.228 \mathrm{X}_{2}+\varepsilon$

Balanced diet has statistically significant effect of school enrolment in $\operatorname{ECD}(\beta=0.228, \mathrm{P}=0.029)$. It implies that a balanced diet significantly and positively relates to children enrolment in ECE centres in Turkana Central Sub County, Turkana County, Kenya. This implies that an increasing balanced diet will lead to an increase in children enrolment in ECE centres in Turkana Central Sub County, Turkana County, Kenya.

\section{CONCLUSION AND RECOMMENDATIONS}

A balanced diet was found to have a statistically significant effect on school enrolment in ECD. In addition, it was revealed that a balanced diet significantly and positively relates to children enrolment in ECE centres in Turkana Central Sub County, Turkana County, Kenya. From these findings, the study concludes that increasing a balanced diet will lead to an increase in children enrolment in ECE centres in Turkana Central Sub County, Turkana County, Kenya.

There is a need to continue the supply of a balanced diet to children because it improves their growth and learning; also, it will ensure the children are in good health and therefore reduce rates of absenteeism as a result of illness. The study found that in some schools there are delays in the food supply, the study, therefore, recommends that the government and other bodies responsible should ensure that there is a timely supply of food to all schools to encourage learners to attend school every day. This will reduce absenteeism and increase rates of enrolment.

\section{SUGGESTION FOR FURTHER STUDIES}

The study was conducted among schools in Turkana Central Sub County; the study recommends replication of the research study in other sub-counties in Turkana County to facilitate generalization of the research findings. The study recommends replication of the study in other counties that experience food scarcity such as Wajir and Mandera Counties. The study focused on the effects of SFPs on enrolment another study should focus on the effects of SFPs on school drop-outs.

\section{REFERENCES}

Ake-Tano, O., Ekou, F.K., Tetchi, E.O., Koffi, K.B., Oussou, K.R., Kpebo, D.O.D., Coulibaly Tiembre, I. \& Koffi K. (2011). Détermination de la malnutrition chez les enfants de moins de 5 ans suivis à l'institut national de santé publique Côte d'Ivoire. Med. Afri. Noir. 58(2),93-99.

Allen, R. (2011). Can school league tables help parents choose schools? Fiscal Studies, 32(2) pp 245-261.

Asres G, \& Eidelman A. I. (2011). Nutritional assessment of Ethiopian Beta-Israel children: A cross-sectional survey. Breastfeed Med, 6, 171176.

Bellisle, F. (2004). Effects of diet on behavior and cognition in children. [Suppl.] British Journal of Nutrition, 92, 227-232.

Bennett, J. (2003). Review of school feeding projects. London: Programme of Advisory Support Services for Rural Livelihoods (PASS), Department of International Development.

Birdsall, N., Levine, R., \& Ibrahim, A. (2005). Towards universal primary education: investments, incentives, and 
institutions. European Journal of Education, 40(3), 337-349.

Bundy, D., Burbano, C., Grosh, M. E., Gelli, A., Juke, M., \& Lesley, D. (2009). Rethinking school feeding: social safety nets, child development, and the education sector. Washington, DC: World Food Programme and the World Bank.

Burbano, C., Neeser, K. \& Bundy, D. A. P. (2009). Cost Analysis of SFP and School Health Options in Malawi. London: PCD.

Central Bureau of Statistics (CBS). (2016). 2016 Basic Education Statistical Booklet. Retrieved from https://www.education.go.ke/

Central Bureau of Statistics, (2011). Kenya Rural Child Nutrition Survey. Ministry of Economic Planning and Development: Nairobi London: St. Louis Toronto

FAO. (2012). Towards the future we want: End hunger and make the transition to sustainable agricultural and food systems. Rome: Food and Agricultural Organization of the United Nations.

Gale, C. R., Martyn, C. N., Marriott, L. D., Limond, J., Crozier, S., Inskip, H. M., ... \& Southampton Women's Survey Study Group. (2009). Dietary patterns in infancy and cognitive and neuropsychological function in childhood. Journal of Child Psychology and Psychiatry, 50(7), 816-823.

Government of India (2014). India's midday meal scheme for school children. Retrieved from www. Government of India. Go. Ke.

Government of India. (2015). About the mid-day meal scheme. Available from Ministry of Human Resource Development, http://mdm.nic.in/aboutus.html.

Hair, J. F., Black, W.C., Babin, B.J., \& Anderson, R. E. (2013). Multivariate Data Analysis (Seventh Edition). Upper Saddle River, NJ: Prentice-Hall.

Halterman J. S., (2011). Iron deficiency and cognitive achievement among school-aged children and adolescents in the United States. Pediatrics, 107(6), 1381-1386.

Jomaa, L. H., McDonnell, E., \& Probart, C. (2011). School feeding programs in developing countries: impacts on children's health and educational outcomes. Nutrition reviews, 69(2), 83-98.

Ndung'u, E. (2010). The Status of School Feeding Program. Unpublished Master's Thesis. Kenyatta University.

Nyaradi, A., Li, J., Hickling, S., Whitehouse, A. J., Foster, J. K., \& Oddy, W. H. (2013). Diet in the early years of life influences cognitive outcomes at 10 years: a prospective cohort study. Acta Paediatrica, 102(12), 1165-1173.

Olubayo, M. A, Amisialuvi, P., \& Namusonge, G. (2013). Factors Affecting Implementation of School Feeding Programmes in Public Primary Schools in Kenya. International Journal of Science and Research ISSN (online), 23197064.

Omoro, J. (2011, 23rd February). School Feeding Program. The Sunday Standard, Retrieved from https://www.standardmedia.co.ke.

OMS, (2010). School meals: building blocks for healthy children. Washington, DC, The National Academies Press. https://doi.org/10.17226/12751.

Orodho, A. J. (2013). Statistics Made UserFriendly for Education and Social Research. Masola Publishers.

Peel, F. (2013, Mar 13). School meals - as good for farmers as they are for children? Retrieved from The Guardian, https://www.theguardian.com/globaldevelopment-professionalsnetwork/2013/mar/15/school-meals-day-foodsecurity-africa

Pollit, E. (1990). Malnutrition and infection in the classroom. Paris: UNESCO.

Simeon, D. T., \& Granham, M. S. (2009). Effects of missing breakfast on the Cognitive Functions of pre-school and school-age children. The 
Indian Experience, American Journal of clinical nutrition, 50(suppl), $675-684$

Tolman, E. C. (1932). Purposive behavior in animals and men. New York: Century.

Vroom, V. H. (1964). Work and motivation. Oxford, England: Wiley.

WHO. (2019). Levels and trends in child malnutrition. Retrieved from, https://www.who.int

World Food Programme (WFP), (2008). Global School Feeding Report 2008, WFP School Feeding Support Unit, Rome, World Food Programme.

World Food Programme (WFP), (2014). Global School Feeding Report 2002, WFP School Feeding Support Unit, Rome, World Food Programme.

World Food Programme (WFP), (2015). Policy Review Report: Early Childhood Care and Education in Kenya. 